\title{
Metabolic physiology of the Mayan cichlid fish (Mayaheros uropthalmus): Re- examination of classification as an oxyconformer
}

\author{
Warren W. Burggren ${ }^{\mathrm{a}}$, Juan Carlos Arriaga-Bernal ${ }^{\mathrm{b}}$, Paola Montserrat Méndez-Arzate ${ }^{\mathrm{b}}$, \\ José Fernando Méndez-Sánchez ${ }^{\mathrm{b}, *}$ \\ ${ }^{a}$ Developmental Integrative Biology Group, Department of Biology, University of North Texas, Denton, TX, USA \\ ${ }^{\mathrm{b}}$ Laboratorio de Ecofisiología Animal, Facultad de Ciencias, Universidad Autónoma del Estado de México, Toluca, Estado de México, Mexico
}

A R T I C L E I N F O

\section{Keywords:}

Cichlids

Oxygen consumption

$\mathrm{P}_{\text {Crit }}$

Respirometry

Oxyregulator

$\mathrm{Q}_{10}$

\begin{abstract}
A B S T R A C T
The Mayan cichlid (Mayaheros uropthalmus) is a freshwater fish inhabiting warm, potentially hypoxic and/or brackish waters, in Mexico and Central America. Despite its description as highly hypoxia tolerant, $M$. uropthalmus has been classified physiologically as an 'oxyconformer', which would place it in a very small (and shrinking) category of fishes that purportedly cannot maintain oxygen consumption $\left(\dot{M} \mathrm{O}_{2}\right)$ as ambient $\mathrm{PO}_{2}$ falls. However, hypoxia tolerance is often associated with strong oxyregulation, not oxyconformation as described for M. uropthalmus. To resolve these inconsistencies, we measured $\dot{M} \mathrm{O}_{2}$, the ambient $\mathrm{PO}_{2}$ at which $\dot{\mathrm{M}} \mathrm{O}_{2}$ begins to decline as $\mathrm{PO}_{2}$ falls $\left(\mathrm{P}_{\text {Crit }}\right)$, and gill ventilation rate $\left(\mathrm{f}_{\mathrm{G}}\right)$ in the Mayan cichlid. Variables were measured at $23^{\circ}, 28$ ${ }^{\circ}$ and $33^{\circ} \mathrm{C}$ and temperature sensitivity $\left(\mathrm{Q}_{10}\right)$ calculated for each function. $\dot{M} \mathrm{O}_{2}$ at air saturation was $2.9 \pm 0.2$, $4.3 \pm 0.4$, and $5.9 \pm 0.3 \mu \mathrm{mol} \mathrm{O} 2 / \mathrm{g} / \mathrm{h}$ at $23^{\circ}, 28^{\circ}$ and $33^{\circ} \mathrm{C}$, respectively. $\mathrm{P}_{\text {Crit }} \mathrm{s}$ were low at $2.6 \pm 0.8 \mathrm{kPa}$, $3.2 \pm 0.8 \mathrm{kPa}$ and $4.7 \pm 0.9 \mathrm{kPa}$ at $23^{\circ}, 28^{\circ}$ and $33^{\circ} \mathrm{C}$, respectively. $\mathrm{Q}_{10}$ values for $\dot{M} \mathrm{O}_{2}$ were $2.56 \pm 0.21(23-$ $28^{\circ} \mathrm{C}$ ), $1.89 \pm 0.15\left(28-33^{\circ} \mathrm{C}\right.$ ) and $2.2 \pm 0.1$ (full temperature range of $23-33^{\circ} \mathrm{C}$ ), suggesting overall $\mathrm{Q}_{10} \mathrm{~S}$ typical for tropical freshwater fish. $\mathrm{f}_{\mathrm{G}}$ was $39 \pm 3,45 \pm 4$, and $53 \pm 6$ breaths $/ \mathrm{min}$ at $23^{\circ}, 28^{\circ}$ and $33^{\circ} \mathrm{C}$, respectively, and increase 2-3 fold in severe hypoxia at each temperature. Experiments employing hyperoxia up to $35 \mathrm{kPa}$ indicate a strong 'hypoxic drive' for gill ventilation. Collectively, these data show that, in contrast to a previous characterization, the Mayan cichlid is a strong oxyregulator exhibiting attributes (e.g. very low $\mathrm{P}_{\text {Crit }}$ ) typical of very hypoxia-tolerant fishes.
\end{abstract}

\section{Introduction}

Many Central and South American fishes have been categorized as hypoxia resistant or tolerant (Almeida-Val et al., 1995; Baptista et al., 2016; Chavez-Lopez et al., 2005; Tian et al., 2017). Among these is the Mayan cichlid, Mayaheros uropthalmus (formerly Cichlasoma uropthalmus). While preferring well oxygenated oligohaline water (Ch́avez-Lopez et al., 2005), this species (also known as the Mexican Mojarra) can live and reproduce in a wide variety of freshwater to slightly brackish habitats (Martínez-Palacios and Ross, 1986; Nico et al., 2007; Schofield et al., 2010; Stauffer and Boltz, 1994). Additionally, the Mayan cichlid shows considerable hypoxia tolerance, as evident from the very low water $\mathrm{PO}_{2}$ thresholds $\left(\sim 20 \mathrm{mmHg}\right.$ at $\left.30{ }^{\circ} \mathrm{C}\right)$ for both aquatic surface respiration (ASR) and buccal air bubble holding (Schofield et al., 2009). This species is also tolerant of high environmental temperatures up to $39^{\circ} \mathrm{C}$, but has limited cold tolerance (Schofield et al., 2010). Perhaps because of its tolerance to a wide variety of environmental conditions, the Mayan cichlid has significant importance to aquaculture in Central America (Martínez-Palacios et al., 1993; Martínez-Palacios and Ross, 2004; Miller et al., 2005). However, this species has also been studied because of its highly invasive nature, expanding into more northerly habitats in the Everglades of Florida, USA and waters in Thailand, for example (Faunce and Lorenz, 2000; Loftus, 1987; Nico et al., 2007; Paperno et al., 2008; Schofield et al., 2009).

Hypoxia tolerance in fishes is often linked to their ability to maintain oxygen consumption even as ambient $\mathrm{PO}_{2}$ falls. An oxyconformer, then is an animal that cannot (or does not) maintain oxygen consumption as ambient $\mathrm{PO}_{2}$ decreases - e.g. (Burggren and Randall, 1978; Rogers et al., 2016; Steffensen, 2007). Conversely an oxyregulator maintains oxygen consumption at or near normoxic levels even as ambient $\mathrm{PO}_{2}$ falls toward the critical $\mathrm{PO}_{2}\left(\mathrm{P}_{\text {Crit }}\right)$, at which point oxygen consumption finally begins to sharply decline. In this context, despite the considerable information available for the Mayan cichlid, a major

\footnotetext{
* Corresponding author.

E-mail address: fms@uaemex.mx (J.F. Méndez-Sánchez).
} 
anomaly persists in the literature. Studying invasive Mayan cichlids from southern Florida, Martínez-Palacios and Ross (1986) described the Mayan cichlid as relatively hypoxia tolerant freshwater fish, as other investigators have before and after. Yet, these authors documented a surprisingly high $\mathrm{P}_{\text {Crit }}$ of approximately $9.3 \mathrm{kPa}(70 \mathrm{mmHg})$. Further, these authors commented quite unequivocally that "...these fish are oxygen conformers and no attempt is made to regulate oxygen uptake". This single reported value of $\mathrm{P}_{\text {Crit }}$ reported for the Mayan cichlid is far higher than values reported for many other tropical freshwater fishes (Rogers et al., 2016). In fact, Rogers et al. (2016) comprehensive meta-analysis of $\mathrm{P}_{\text {Crit }}$ in fishes, $<10 \%$ of 72 observations of 33 species freshwater fish tested at temperatures of $20-36{ }^{\circ} \mathrm{C}$ had $\mathrm{P}_{\text {Crit }}$ values higher than that reported for the Mayan cichlid by Martínez-Palacio and Ross (1986).

A high $\mathrm{P}_{\text {Crit }}$ for Mayan cichlids would seemingly be in stark contrast to the view that hypoxic resistance in fishes is generally associated with a lower value for $\mathrm{P}_{\text {Crit }}$ (Burggren et al., 2019; Mandic et al., 2009; Reardon and Chapman, 2010; Rogers et al., 2016). Indeed, Stephensen (2007), in discussing the likelihood that any fish is an oxyconformer, comments "Overall, most fish species behave as perfect oxygen regulators". It could be proposed that the Mayan cichlid's hypoxic resistance derives from the ability to tolerate tissue hypoxia as ambient $\mathrm{PO}_{2}$ falls - i.e. oxyconform - rather than resisting hypoxia by increasing gill ventilation and oxygen extraction to maintain arterial oxygen transport. Yet, if Mayan cichlids are indeed "oxyconformers", it would place this species in an extremely small category of vertebrates that are putative oxyconformers.

The rather surprising finding of a high $\mathrm{P}_{\text {Crit }}$ for the Mayan cichlid reported in just a single study by Martínez-Palacios and Ross (1986), and their subsequent conclusion that this fish is an "oxyconformer", has gone unchallenged for $>30$ years, surprising given the general acceptance of hypoxia tolerance by the Mayan cichlid,.. Moreover, the metabolic physiology of Mayan cichlids has not been extensively investigated over a range of temperature and oxygen levels. Consequently, we have investigated the relationship between oxygen consumption, gill ventilation frequency and ambient water $\mathrm{PO}_{2}$ at three different temperatures for $M$. uropthalmus. We hypothesized that, despite a previous report, the Mayan cichlid is indeed representative of typical Central and South American cichlids and indeed many tropical fishes, acting as an oxyregulator maintaining oxygen consumption until experiencing low ambient $\mathrm{PO}_{2} \mathrm{~S}$.

\section{Methods}

\subsection{Fish acquisition and maintenance}

Young adult Mayan cichlids were captured in the wild in Tabasco State, and transported to Toluca, Estado de México, Mexico, where they were maintained for three months at $27.5{ }^{\circ} \mathrm{C}$ in filtered, air-saturated water (pH 8.0-8.1, hardness 240-280 $\mathrm{mg} \mathrm{CaCO}_{2} / 1,\left[\mathrm{NH}_{3}\right]<0.5 \mathrm{mg} / \mathrm{l}$, total dissolved solids $0.8-0.29 \mathrm{ppt}$ ). Fish were kept in a 2401 tank at a stocking density of $<1.4 \mathrm{~g} / \mathrm{l}$. All fish were exposed to a natural daylight cycle, approximately 13:11 light:dark during the season in which these experiments were performed. Fish were fed ad libitum twice daily with a diet of commercial fish food, and their length and weight measured weekly. Average body mass increase during this 3 month period was $10.7 \pm 3.6 \mathrm{~g}(20.8 \pm 4.6 \%)$. No deaths (except as a result of cannibalism) occurred during the three-month acclimation period used in metabolic experiments.

\subsection{Oxygen consumption measurements}

Routine mass-specific oxygen consumption $\left(\dot{M} \mathrm{O}_{2}, \mu\right.$ mol $\left.\mathrm{O}_{2} / \mathrm{g} / \mathrm{h}\right)$ was measured using closed respirometry in young, sexually mature $M$. uropthalmus (body mass $55.4 \pm 8.1 \mathrm{~g}, n=6$ ) that had been fasting for $12-16 \mathrm{~h}$, to minimize any influence of specific dynamic action. Acrylic cylindrical containers with $2-3 \mathrm{~mm}$ thick transparent walls were used as respirometers. Two sizes were used (volumes $880 \mathrm{ml}$ or $1376 \mathrm{ml}$ ), depending upon fish mass. The opaque lid of each respirometer contained a valved inlet and outlet. Respirometers were submerged in a 1201 glass tank, maintained at the desired experimental temperature of $23^{\circ}, 28^{\circ}$ or $33^{\circ} \mathrm{C}$. The tank containing the respirometers was wrapped with opaque material to shield the investigators' movements. Respirometers were oriented so that the opaque lid prevented fish from observing each other while in the respirometers.

Each fish was placed in a respirometer and then allowed to acclimate to respirometer conditions for $\sim 2 \mathrm{~h}$. During this acclimation period, the respirometer was continuously flushed with air-equilibrated water pumped from a small submersible water pump at a rate of $450-600 \mathrm{ml} / \mathrm{min}$, thus turning over the volume of the respirometer every 2-3 min. Special care was taken to ensure that no air bubbles were trapped within the respirometer. Following respirometer acclimation, the valves on the inlet and outlet of the respirometer lid were carefully closed without disturbing the fish, which began the metabolic measurements. Importantly, recorded values of $\mathrm{MO}_{2}$ in the first minutes of after measurements began were very similar to those taken $1-2 \mathrm{~h}$ into the respirometry run, as long as the $\mathrm{PO}_{2}$ was above $\mathrm{P}_{\text {Crit }}$. This indicates that the initial $2 \mathrm{~h}$ acclimation period was sufficient for the fish to return to resting conditions after handling for initial placement in the respirometer. The decline in $\mathrm{PO}_{2}$ within each sealed respirometer containing a fish, and the associated instantaneously calculated $\mathrm{MO}_{2}$, was measured until $\dot{M} \mathrm{O}_{2}$ values, which had previously been more or less stable, began to sharply decline with further decrease in $\mathrm{PO}_{2}$. This inflection point represented the arrival at the fish's $\mathrm{P}_{\text {Crit }}$, which was subsequently calculated after the measurement was completed (see below). $\mathrm{P}_{\text {Crit }}$ was typically reached in $2-6 \mathrm{~h}$ depending on the fish's body mass, temperature and rate of $\mathrm{O}_{2}$ consumption. $\dot{M} \mathrm{O}_{2}$ measurements were continued for a maximum of 15 min after the $\mathrm{P}_{\text {Crit }}$ inflection, after which the valves on the respirometers containing the fish were then opened to allow continuous flushing with air-saturated water.

$\mathrm{PO}_{2}$ decline in each respirometer due to the fish's respiration was measured using temperature-compensated fiber-optic planar sensors (PreSens) connected to a Witrox $4 \mathrm{~m}$ (Loligo Systems ApS). Each respirometer had an optode sensor attached to the inside of the respirometer wall. A fiber optic laser probe both causing and capturing fluorescence in the internal optode sensor was attached perpendicularly to the outside of the respirometer immediately opposite the internal optode sensor. Fluorescence signals from the optode sensorsensors were captured with a computer running AutoResp software (Loligo Systems $\mathrm{ApS}$ ). Mass-specific oxygen consumption was calculated from the rate of $\mathrm{O}_{2}$ decline in each chamber over time, the chamber volume, the elapsed time, and the mass off the fish, after (Burggren et al., 2019). Blank respirometers were run to determine microbial respiration. There was no stirring in these blanks, which has been suggested to disproportionately affect the accuracy of the amount of microbial respiration subtracted from the total $\dot{M} \mathrm{O}_{2}$ (Rodgers et al., 2016). However, our blank measurements revealed no detectable oxygen consumption due to microbial respiration, so there was no need to apply a correction to the metabolic data for the fish.

No active stirring was provided within the sealed respirometers. Preliminary direct observations of fishes in the respirometers were made through a small observation port in the covering of the holding tank. These preliminary observations revealed significant water stirring within the respirometer, evident from the movements of small particulate matter in the water in these initial experiments. Stirring and mixture of water in the respirometer was caused by the fish, itself, as a result of pectoral, pelvic and tail fin movements to maintain position, as well as occasional exploratory behavior including occasional turning around in the respirometer. Importantly, this considerable stirring and water mixing was occurring in the area where the PreSens sensor was located, preventing any build-up of boundary layers adjacent to the respirometer wall.

In addition to visual verification of stirring, evidence of adequate 
continuous stirring came from the measurements, themselves. The Loligo software was set to sample $\mathrm{PO}_{2}$ in each respirometer every second and from that calculate an instantaneous $\dot{M} \mathrm{O}_{2}$. The software also calculated a $\mathrm{r}^{2}$ value for the regression through the preceding 60 $\dot{\mathrm{MO}} \mathrm{O}_{2}$ determinations to indicate $\mathrm{PO}_{2}$ measurement variability. A high $\mathrm{r}^{2}$ would indicate the desired low sample to sample variability across multiple $\dot{M} O$ measurements, whereas a low $\mathrm{r}^{2}$ would indicate a high sample to sample variability, which could arise from insufficient or irregular stirring within the respirometers. $\mathrm{R}^{2}$ values in these measurements were typically in the range of $0.96-0.99$, indicating very little measurement-to-measurement variability in sampled $\mathrm{PO}_{2}$.

Given that fish during the actual $\mathrm{P}_{\text {Crit }}$ runs were assumed to be exhibiting similar movements (and producing stirring within the respirometer), we thus classified the metabolic measurements as "routine" oxygen consumption. (See Discussion for additional comments on methodology).

Finally, because the laboratory in which fish were acclimated and measured is located at an altitude of $\sim 2650 \mathrm{~m}$ in Toluca, "normoxia" is actually a $\mathrm{PO}_{2}$ of $\sim 15 \mathrm{kPa}$, compared to $\sim 19.6 \mathrm{kPa}$ at sea level. To approximate acute conditions of sea level, compressed $\mathrm{O}_{2}$ gas was injected into the water flushing the respirometers to raise its $\mathrm{PO}_{2}$ to $\sim 20 \mathrm{kPa}$, which served as the starting point for the $\mathrm{P}_{\text {Crit }}$ runs.

\subsection{Critical $\mathrm{PO}_{2}$ calculation}

$\mathrm{P}_{\text {Crit }}$ is the $\mathrm{PO}_{2}$ below which oxygen consumption cannot be maintained as ambient $\mathrm{PO}_{2}$ falls. Assessment of $\mathrm{P}_{\text {Crit }}$ is typically determined by examining the entire relationship between ambient $\mathrm{PO}_{2}$ and $\dot{\mathrm{MO}} \mathrm{O}_{2}$, and then either visually or statistically determining the break point in this relationship at which $\dot{M} \mathrm{O}_{2}$ rapidly falls with further decreases in ambient $\mathrm{PO}_{2}$. In this study we determined $\mathrm{P}_{\text {Crit }}$ by using a modified"broken stick" statistical regression methodology (Yeager and Ulstch, 1989). This procedure identifies the $P_{\text {Crit }}$ from the intersection point of two separate lines that best fit all $\dot{M} \mathrm{O}_{2}$ data points above and all below the $\mathrm{PO}_{2}$ approximating $\mathrm{P}_{\text {Crit }}$, evident from the sharp inflection in the relationship between ambient $\mathrm{PO}_{2}$ and $\mathrm{MO}_{2}$. Essentially, this process starts by determining the $\dot{M} \mathrm{O}_{2}$ values above the inflection that result in a r $^{2}$ of 0 - that is, indicating that there is no relationship between $\dot{M O}_{2}$ and decreasing $\mathrm{PO}_{2}$ (e.g. oxyregulation). An accompanying $\mathrm{r}^{2}$ is then calculated for a second regression line created from the remaining points below the apparent $\mathrm{P}_{\text {Crit }}$. Next, a data point for $\dot{M} \mathrm{O}_{2}$ formerly contributing to the regression above the $\mathrm{P}_{\text {Crit }}$ line for higher $\mathrm{PO}_{2} \mathrm{~S}$ is moved to the pool of values contributing to the lower regression line, and the effect on the resulting $\mathrm{r}^{2}$ value of that regression is determined. This process is repeated for with multiple successive regressions, repeatedly moving data points from one regression line to the other, until the $r^{2}$ of the upper regression remains a 0 while the $r^{2}$ for the lower regression line reaches its maximum value, indicating the best overall fit of the two regressions for the $\dot{M} \mathrm{O}_{2}$ data. The intersection of these final two regressions thus identifies the $\mathrm{P}_{\text {Crit }}$. Typically, the $\mathrm{r}^{2}$ for the lower regression line below the $\mathrm{P}_{\text {Crit }}$ ended at a value of $>0.90$.

\subsection{Experimental protocols for $\mathbf{M O}_{2}$ measurements}

\subsubsection{Effects of multiple successive $\dot{\mathbf{M}} \mathbf{O}_{2}$ measurements}

An initial set of experiments was carried at $28^{\circ} \mathrm{C}$ to document the recovery in normoxia or near-normoxia of the fish following a $\mathrm{P}_{\text {Crit }}$ respirometer run, and to determine any apparent effects (e.g. generation of an $\mathrm{O}_{2}$ debt) created by exposure to the low $\mathrm{PO}_{2} \mathrm{~S}$ necessary to determine $\mathrm{P}_{\text {Crit }}$ (Fig. 1). Thus, a first respirometry run was conducted as described in Section 2.2., continuously measuring $\dot{\mathrm{MO}}_{2}$ as $\mathrm{PO}_{2}$ progressively fell to $\mathrm{P}_{\text {Crit }}$ and slightly below. After the first measurement taken while the respirometer was near-normoxia (far left $\mathrm{MO}_{2}$ value in Fig. 1), the $P_{\text {Crit }}$ run was completed, and the valves in the respirometer lids were then opened to flush the interior of the respirometer with airsaturated water at $\sim 20 \mathrm{kPa}$ for a standard $\sim 2 \mathrm{~h}$ acclimation period (hours 2-4 in Fig. 1). Then, three rapid successive "recovery" $\mathrm{MO}_{2}$ measurements were made during which the $\mathrm{PO}_{2}$ in the respirometers was not allowed to fall to lower than $14-16 \mathrm{kPa}$ (i.e. near normoxia) during each recovery run, with an intervening $10 \mathrm{~min}$ period of respirometer flushing with air-saturated water occurring between runs. These much more rapid $\dot{\mathrm{O}}_{2}$ measurements in normoxia typically required only $15-45 \mathrm{~min}$. The averaged value for these three replicates is indicated as the second bar from the left in Fig. 1. After these three replicate measurements, the respirometer valves were opened and the respirometer continuously flushed overnight with air saturated water. The next morning, $\sim 14 \mathrm{~h}$ later, the respirometers were sealed and third set of $\dot{M} \mathrm{O}_{2}$ measurements were made (2nd bar from right, Fig. 1), following the same protocol as previous measurements. Finally, to assess the possibility of any $\mathrm{O}_{2}$ limitation to oxygen consumption at the ambient air-saturated $\mathrm{PO}_{2}$ of Toluca $(\sim 17 \mathrm{kPa})$, or as a result of accumulation of possible unpaid $\mathrm{O}_{2}$ debt from the previous $\dot{M O}_{2}$ measurements, the respirometers were flushed with hyperoxic water $\left(\mathrm{PO}_{2} \sim 23 \mathrm{kPA}\right.$, $28^{\circ} \mathrm{C}$ ), generated by bubbling water with pure $\mathrm{O}_{2}$ gas. A final series of three rapid, successive $\dot{M} \mathrm{O}_{2}$ measurements were made in hyperoxia (right hand-most bars in Fig. 1).

\subsubsection{Effects of acute temperature change on $\dot{\mathrm{M}} \mathrm{O}_{2}$}

The next set of experiments were conducted two days after the first set described above. The cichlids, which had been held at $28^{\circ} \mathrm{C}$ since arriving in the laboratory, were placed into the respirometers being flushed with air saturated water at $28{ }^{\circ} \mathrm{C}$ and allowed to acclimate in the respirometers for $2 \mathrm{~h}$. The respirometers were then sealed and a $\mathrm{P}_{\text {Crit }}$ run employing multiple successive $\mathrm{MO}_{2}$ measurements was was made at $28^{\circ} \mathrm{C}$. After these initial measurements $28^{\circ} \mathrm{C}$, taking $\sim 3-5 \mathrm{~h}$ depending upon the particular fish, the fish were removed from the respirometers, fed during a $2 \mathrm{~h}$ period at $28^{\circ} \mathrm{C}$, and then returned to the respirometers, which were constantly flushed with air saturated water. The temperature of the water entering the respirometers was than lowered over a $2 \mathrm{~h}$ period to $23^{\circ} \mathrm{C}$ (rate of temperature change $2.5^{\circ} \mathrm{C} / \mathrm{h}$ ), and the fish allowed to acclimate overnight to this lower temperature for $\sim 12-14 \mathrm{~h}$. The $\dot{M} \mathrm{O}_{2}$ and $\mathrm{P}_{\text {Crit }}$ measurement process was then repeated, after which fish were once again fed over a $2 \mathrm{~h}$ period and then returned to the respirometer. The temperature was then raised to $33^{\circ} \mathrm{C}$ over a four hour period (rate of temperature change $\sim 2.5^{\circ} \mathrm{C}$ / h) and the fish acclimated overnight at this new higher temperature. The following day, $\dot{\mathrm{M}} \mathrm{O}_{2}$ and $\mathrm{P}_{\text {Crit }}$ measurements were made at $33^{\circ} \mathrm{C}$.The following day, $\mathrm{MO}_{2}$ and $\mathrm{P}_{\text {Crit }}$ measurements were made at $23^{\circ} \mathrm{C}$.

\subsection{Gill ventilation frequency measurements}

In a final set of experiments conducted over a three day period following the $\dot{M} \mathrm{O}_{2}$ measurements had been completed, Mayan cichlids were placed individually in respirometers for the standard $\sim 2 \mathrm{~h}$ acclimation period in water at $28^{\circ} \mathrm{C}$ at a $\mathrm{PO}_{2}$ of $\sim 20 \mathrm{kPa}$. Gill ventilation frequency, $\mathrm{f}_{G}$ (breaths/min), was determined by direct visual observation of opercular movements through a small observation port in the cover of the tank holding the respirometers, taking care to avoid disturbing the fish within the respirometers. Two to three successive measurements of $\mathrm{f}_{G}$ were made over a $60 \mathrm{~s}$ period, and the values averaged to create the mean $\mathrm{f}_{\mathrm{G}}$ at the measurement $\mathrm{PO}_{2}$. Two initial $\mathrm{f}_{G}$ measurements over a $30 \mathrm{~min}$ period were made, and the respirometers then closed and the internal water $\mathrm{PO}_{2}$ allowed to diminish over several hours to below the $\mathrm{P}_{\text {Crit }}$ level, recording $\mathrm{f}_{G}$ at numerous times as $\mathrm{PO}_{2}$ progressively fell. These experiments were repeated at $33^{\circ} \mathrm{C}$ and $23^{\circ} \mathrm{C}$ over two successive days, following the same protocol as described for the $\dot{M} \mathrm{O}_{2}$ measurements at multiple temperatures.

Experiments were also conducted to assess if there was an 'hypoxic drive' to gill ventilation in the Mayan cichlid, and whether there were any differences between 'normoxic' ventilation rates at sea level and the elevation of Toluca. To determine this, ambient $\mathrm{PO}_{2}$ of water flushing 


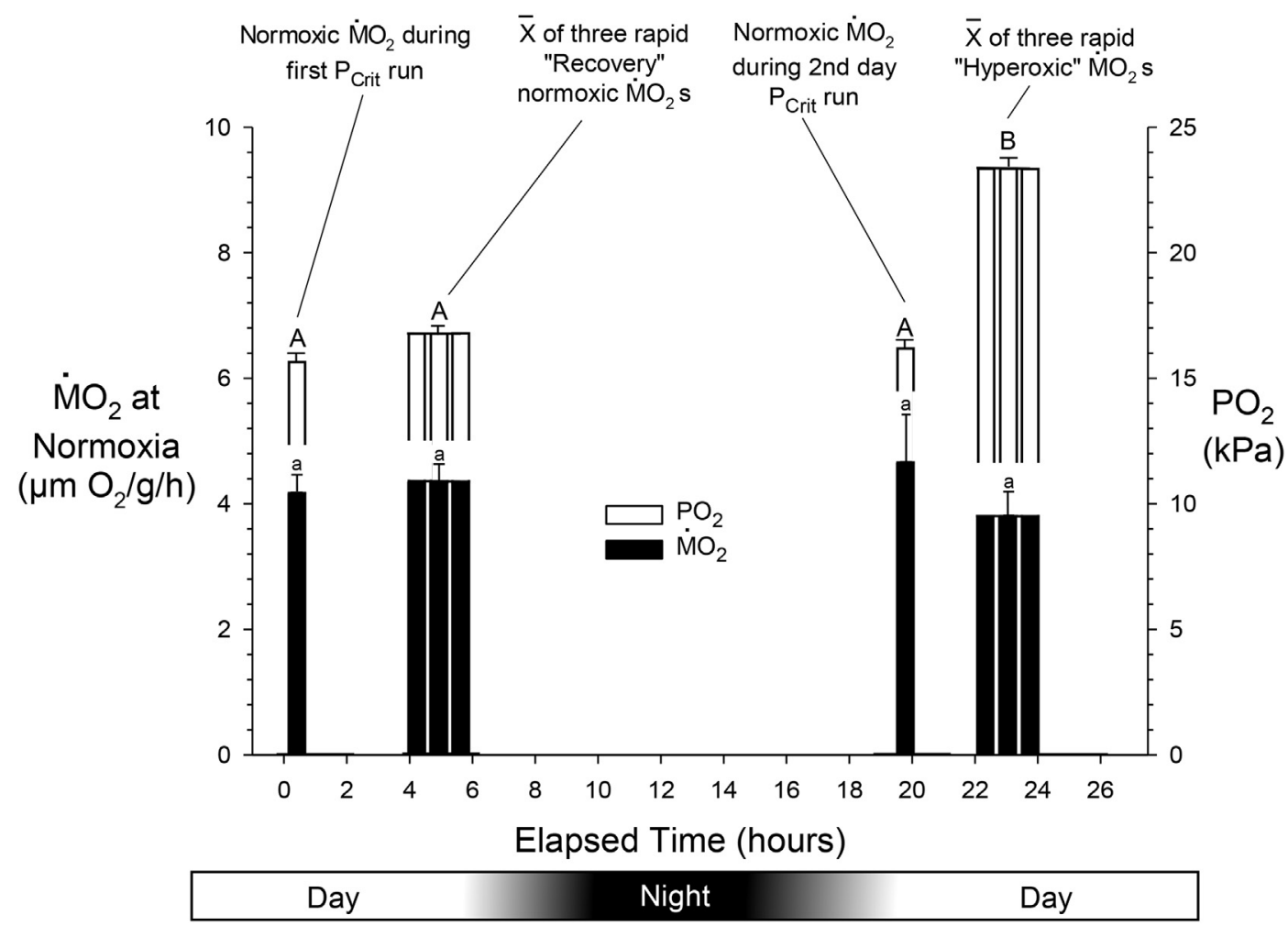

Fig. 1. Oxygen consumption at $28^{\circ} \mathrm{C}$ in Mayan cichlids (Mayaheros uropthalmus) measured at distinct, successive periods over $\sim 24 \mathrm{~h}$ to assess the effects of repeated PCrit measurements and of hyperoxia. The plotted $\dot{M O}_{2}$ (left Y-axis) was measured at the associated $\mathrm{PO}_{2}$ (right Y-axis). The initial left-most $\dot{\mathrm{MO}} \mathrm{O}_{2}$ was the value measured in normoxia $(\sim 15.5 \mathrm{kPa})$ at the beginning of the first full $\mathrm{P}_{\text {Crit }}$ run. The next plotted $\dot{\mathrm{M}} \mathrm{O}_{2}$ value to the right of that first run represents the mean of three replicates in normoxia completed in rapid succession over a two hour period, $\sim 3 \mathrm{~h}$ after the first $\mathrm{P}_{\text {Crit }}$ run. Then, after a $\sim 14 \mathrm{~h}$ overnight period, a second full $\mathrm{P}_{\text {Crit }}$ run beginning with normoxia was conducted, and the initial normoxic $\dot{M O}_{2}$ value from that run plotted. Finally, to determine the effects, if any, of hyperoxia on $\dot{M} \mathrm{O}_{2}$, a second set of three replicates completed in rapid succession over a two hour period were conducted in hyperoxia $(\sim 23 \mathrm{kPa})$. For all plots, upper and lower case letters indicate significance of differences between mean $\mathrm{PO}_{2} \mathrm{~s}$ and mean $\dot{\mathrm{MO}}_{2} \mathrm{~s}$ assessed by One-way ANOVA. Values presented are means \pm se. $n=6$ fish for all measurements. See text for additional details.

the respirometers was raised by injected $\mathrm{O}_{2}$ gas into the water flushing the respirometers to achieve a $\sim 35 \mathrm{kPa}$, nearly twice the level of oxygen at which the fish were acclimated. The respirometers were then closed, and $\mathrm{f}_{G}$ measured at $28^{\circ} \mathrm{C}$ as described above until $\mathrm{PO}_{2}$ fell to $\sim 15 \mathrm{kPa}$, levels slightly below normoxia in Toluca. This procedure for measuring gill ventilation was repeated over two successive days at $33^{\circ} \mathrm{C}$ and $23^{\circ} \mathrm{C}$.

\subsection{Statistics}

One-way repeated measures ANOVAs were performed for each temperature to test significant differences in $\mathrm{MO}_{2}$ and $\mathrm{P}_{\text {Crit }}$. Two-way ANOVA (i.e. temperature and $\mathrm{PO}_{2}$ as covariables for the $\mathrm{MO}_{2}$ and $\mathrm{f}_{\mathrm{G}}$ determinations) was considered but then rejected as a statistical approach, since the temperature measurements were performed on separate days with an intervening period $1 / 2$ day period in which the fish were removed from the respirometer, fed and then replaced in the respirometer, indicating that each respirometry run was an independent event rather than a repeated measure under the same conditions.

Following one-way repeated measures, Holm-Sidak multiple comparison procedures were then used to determine significant differences between $\dot{M O}_{2}$ s and $\mathrm{f}_{G} \mathrm{~s}$ at different ambient $\mathrm{PO}_{2}$ levels and at different temperatures.

A significance level of 0.05 was employed for all statistical tests to accept significant differences between experimental groups.

\section{Results}

\subsection{Oxygen consumption}

\subsubsection{Assessment of experimental protocol effects}

To determine if there was any effect on $\mathrm{MO}_{2}$ of sequential exposure to $\mathrm{PO}_{2}$ s below the Mayan cichlid's $\mathrm{P}_{\text {Crit }}$, we compared $\mathrm{MO}_{2}$ in normoxia before the first $\mathrm{P}_{\text {Crit }}$ run, then after a $4 \mathrm{~h}$ recovery, and again after $\sim 12-14 \mathrm{~h}$. A final measurement was made in hyperoxia $(\sim 23 \mathrm{kPa})$ to determine whether $\dot{M} \mathrm{O}_{2}$ might be oxygen-limited by the ambient $\mathrm{PO}_{2} \mathrm{~S}$ of Toluca or previous $\mathrm{P}_{\text {Crit }}$ measurement runs. There were no significant differences $(P>.10)$ between $\dot{M O}_{2}$ values measured under any of the normoxic conditions described above and depicted in Fig. 1, including the final $\mathrm{P}_{\text {Crit }}$ run in hyperoxia. Nor was there a significant difference $(P>.05)$ between the $\mathrm{P}_{\text {Crit }} \mathrm{s}$ determined in the first $\mathrm{P}_{\mathrm{Cri}} \mathrm{t}$ run at time $=0$ to $3 \mathrm{~h}$ and the second run at time $=19-22 \mathrm{~h}$ in Fig. 1 .

\subsubsection{Acclimation temperature, ambient $\mathrm{PO}_{2}$ and $\mathrm{MO}_{2}$}

Oxygen consumption at the ambient $\mathrm{PO}_{2}$ of Toluca $(\sim 15 \mathrm{kPa})$ was $2.9 \pm 0.2,4.3 \pm 0.4$, and $5.9 \pm 0.3 \mu \mathrm{mol} \mathrm{O}_{2} / \mathrm{g} / \mathrm{h}$ at $23^{\circ}, 28^{\circ}$ and $33^{\circ} \mathrm{C}$, respectively (Fig. 2). These values translated into $\mathrm{Q}_{10}$ values for $\dot{M} \mathrm{O}_{2}$ of $2.56 \pm 0.21$ for the temperature range of $23-28^{\circ} \mathrm{C}$ and $1.89 \pm 0.15$ for the temperature range of $28-33^{\circ} \mathrm{C}$ (Fig. 3). $\mathrm{Q}_{10}$ for $\dot{M} \mathrm{O}_{2}$ over the total temperature range of $23-33^{\circ} \mathrm{C}$ was $2.18 \pm 0.10$.

Ambient $\mathrm{PO}_{2}$ significantly $(P<.001)$ affected $\dot{M} \mathrm{O}_{2}$ for all three measurement temperatures (Fig. 3). $\mathrm{P}_{\text {Crit }}$ values calculated from the decline in $\mathrm{MO}_{2}$ at low ambient $\mathrm{PO}_{2}$ s were $2.60 \pm 0.76,3.17 \pm 0.79$ and $4.68 \pm 0.91 \mathrm{kPa}$ at $23^{\circ}, 28^{\circ}$ and $33^{\circ} \mathrm{C}$, respectively. These comparably low $\mathrm{P}_{\text {Crit }}$ values compared to other cichlids and most other fishes indicates that the Mayan cichlid is a strong oxyregulater. 


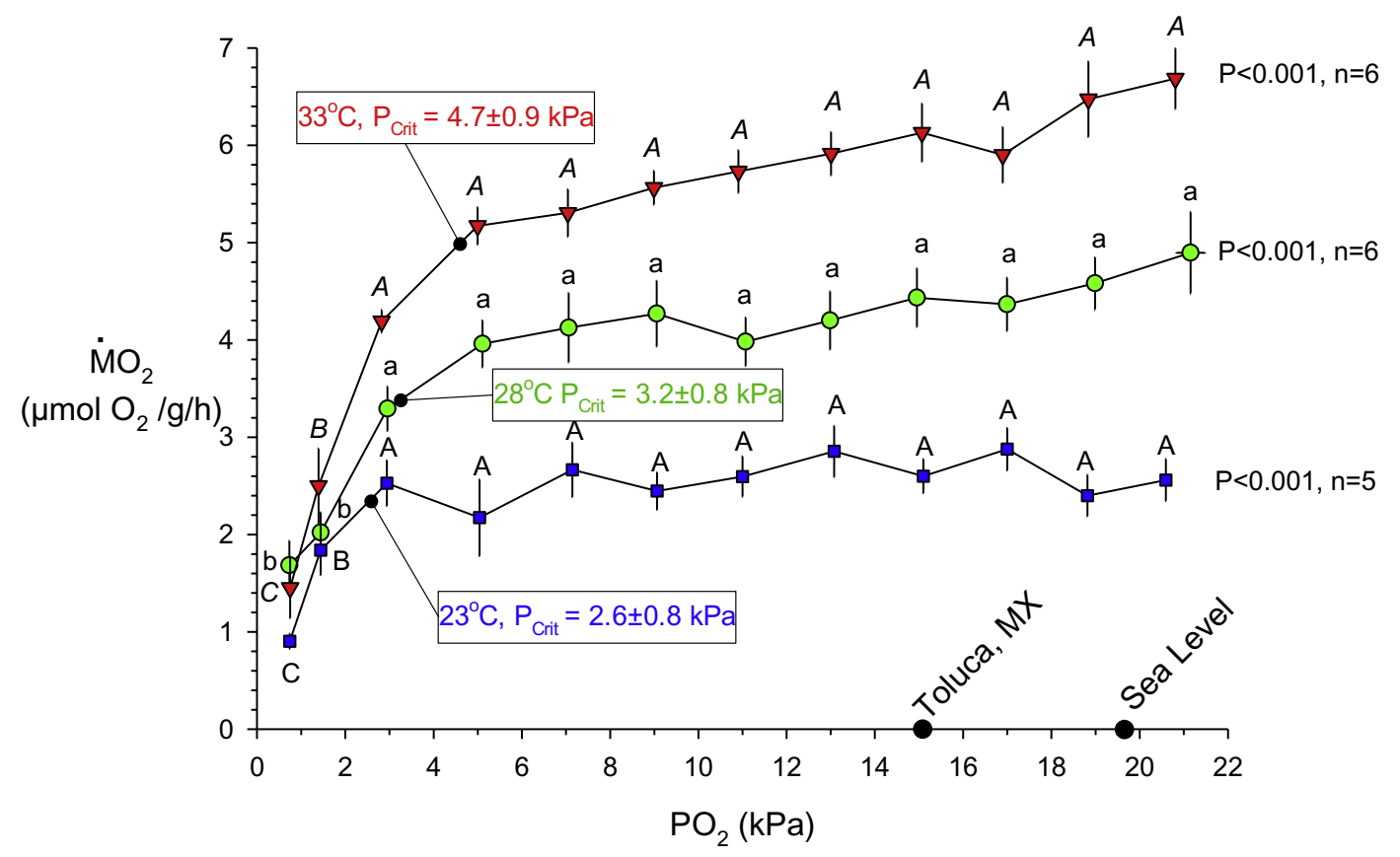

Fig. 2. Relationship between oxygen consumption $\left(\mathrm{MO}_{2}\right)$ and ambient $\mathrm{PO}_{2}$ in the Mayan cichlid (Mayaheros uropthalmus) measured after 12-14 h acclimation at $28^{\circ}$, then $33^{\circ}$ and finally $23^{\circ} \mathrm{C} . \mathrm{PO}_{2} \mathrm{~S}$ at important oxygen levels are indicated on the x-axis. Lower case, upper case and upper case italic letters indicate significance of differences between individual means. ANOVAS and $\mathrm{n}$ values are indicated to right of each data plot. Values presented are means \pm se.

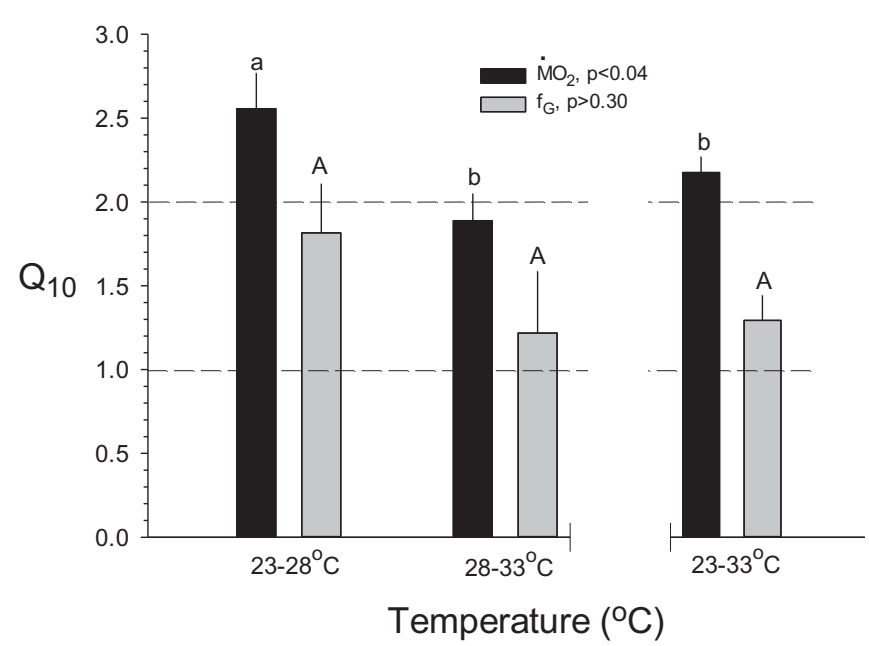

Fig. 3. Temperature sensitivities, expressed as $Q_{10}$, for oxygen consumption $\left(\dot{M O}_{2}\right.$, black bars) and gill ventilation rate $\left(\mathrm{f}_{\mathrm{G}}\right.$, gray bars) in the Mayan cichlid (Mayaheros uropthalmus). $\mathrm{Q}_{10} \mathrm{~s}$ for each variable measured at air-saturation levels were calculated over the $5^{\circ} \mathrm{C}$ intervals of $23-28^{\circ}$ and $28-33^{\circ} \mathrm{C}$ (two sets of bars on left of figure) and over the $10^{\circ} \mathrm{C}$ interval $23-33^{\circ} \mathrm{C}$ (single set of bars after the $\mathrm{X}$-axis break on the right). Horizontal dashed lines indicate $\mathrm{Q}_{10}$ values of 1.0 and 2.0. Lower case letters, applying to $\dot{\mathrm{M}} \mathrm{O}_{2}$, and upper case letters, applying to $\mathrm{f}_{\mathrm{G}}$, indicate significant differences between $\mathrm{Q}_{10}$ means for each variable, assessed by One-way Repeated Measures ANOVA. Values presented are means \pm se. $n=5$ for temperature intervals $23-28^{\circ} \mathrm{C}$ and $23-33^{\circ} \mathrm{C}$ and $\mathrm{n}=6$ for interval $28-33^{\circ} \mathrm{C}$.

Further indication of a high tolerance to hypoxia is that all fish recovered from brief exposure to ambient $\mathrm{PO}_{2} \mathrm{~s} 1-1.5 \mathrm{kPa}$ below their $\mathrm{P}_{\text {Crit. }}$

\subsection{Gill ventilation frequency}

\subsubsection{Acclimation temperature, ambient $\mathrm{PO}_{2}$ and $f_{G}$}

As anticipated, gill ventilation increased with increasing temperature and declining ambient $\mathrm{PO}_{2}$ (Fig. 4) $\mathrm{f}_{\mathrm{G}}$ at (16-17 kPa was $39 \pm 3,45 \pm 4$, and $53 \pm 6$ breaths $/ \mathrm{min}$ at $23^{\circ}, 28^{\circ}$ and $33^{\circ} \mathrm{C}$, respectively. These values translated into $Q_{10}$ values for $f_{G}$ of $2.56 \pm 0.21$ for the temperature range of $23-28^{\circ} \mathrm{C}$ and $1.23 \pm 0.35$ for the temperature range of $28-33^{\circ} \mathrm{C}$ (Fig. 3). $\mathrm{Q}_{10}$ for $\mathrm{f}_{G}$ over the total temperature range of $23-33^{\circ} \mathrm{C}$ was $1.30 \pm 0.12$.

\subsubsection{Hyperoxia and the "hypoxic drive" for Gill ventilation}

Gill ventilation was also measured at $\mathrm{PO}_{2} \mathrm{~s}$ acutely above normoxia. $\mathrm{PO}_{2}$ over the range of $\sim 15-35 \mathrm{kPA}$ significantly $(\mathrm{P}<.001)$ altered $\mathrm{f}_{\mathrm{G}}$ at all three temperatures (Fig. 4B). At $33^{\circ} \mathrm{C}$, for example, $\mathrm{f}_{\mathrm{G}}$ decreased from $\sim 53$ breaths/min down to only 29 breaths $/ \mathrm{min}$ at $35 \mathrm{kPa}$ and just $23 \mathrm{breaths} / \mathrm{min}$ at $35 \mathrm{kPa}$. Similar patterns were evident at the other two measurement temperatures (Fig. 4B), collectively indicating a considerable hypoxic ventilatory drive in the Mayan cichlid.

\section{Discussion}

\subsection{Critique of the methodology}

An assumed lack of stirring associated with closed respirometry has been suggested as a confounding factor affecting $\dot{M} \mathrm{O}_{2}$ and $\mathrm{P}_{\text {Crit }}$ measurements in fishes (Rodgers et al., 2016; Rogers et al., 2016; Steffensen, 2007). Small, relatively lethargic fishes may not provide sufficient stirring when placed in large respirometers. As noted in the Methods section above, while no experimental stirring was provided by the experimental apparatus in the current experiments, relatively thorough stirring within the apparatus provided by the movements of the fish was documented (see Methods Section 2.2). Moreover, values of $\dot{M} \mathrm{O}_{2}$ for the Mayan cichlid were very comparable with similar fishes at similar temperatures measured using a variety of techniques (Table 1).

Regarding $\mathrm{P}_{\text {Crit }}$ determination, there has been a long-standing debate about the merits of closed vs. open respirometry, with three recent studies in particular thoroughly summarizing the arguments - and coming to quite different conclusions (Regan et al., 2017; Rogers et al., 2016; Snyder et al., 2016). 


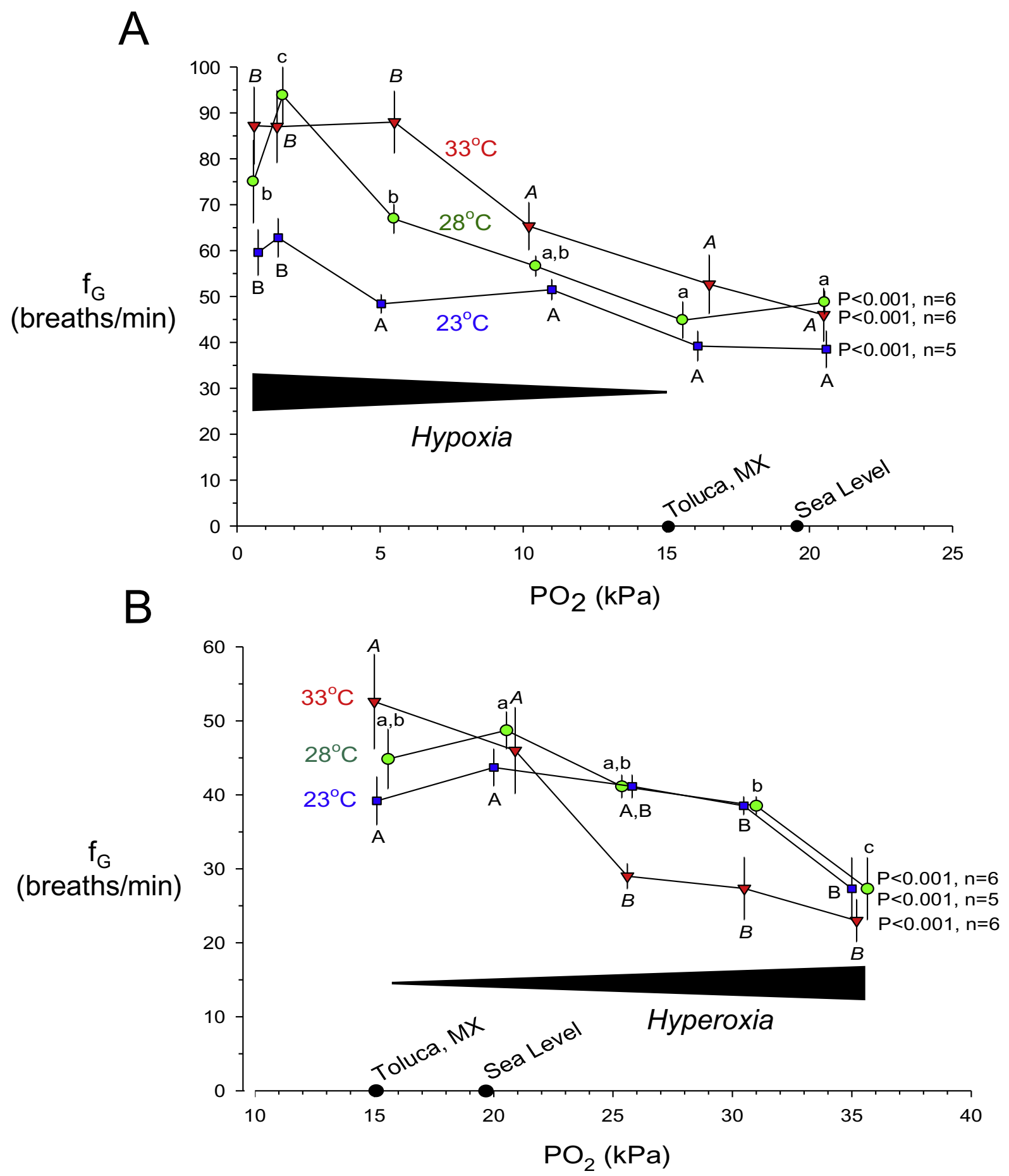

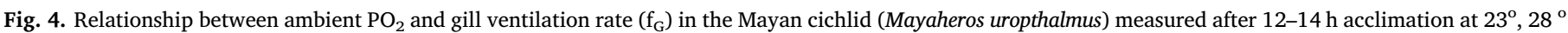

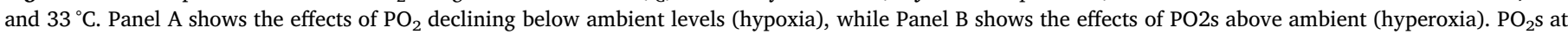

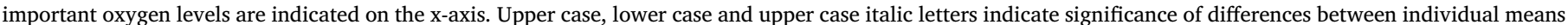
for $28^{\circ}, 23^{\circ}$ and $33^{\circ} \mathrm{C}$ data, respectively. ANOVAS and $\mathrm{n}$ values are indicated to right of each data plot. Values presented are means \pm se.

Contributing to the debate, a careful set of experiments has compared closed and open respirometry for measuring $\mathrm{MO}_{2}$ and $\mathrm{P}_{\text {Crit }}$ in the goldfish Carassius auratus auratus at $17^{\circ} \mathrm{C}$ (Regan and Richards, 2017). Importantly, this study additionally used calorespirometry, suggested to be the "gold standard" for metabolic measurements, to calibrate and standardize their findings. Their results for the goldfish indicated no significant differences between respirometry techniques in either $\mathrm{MO}_{2}$ or $\mathrm{P}_{\text {Crit }}$ measured over a wide range of $\mathrm{PO}_{2}$ s. Moreover, there was no buildup of metabolic end-products during $4 \mathrm{~h}$ of deep hypoxia. Build-up of metabolic products - especially $\mathrm{CO}_{2}$ - has been suggested as a possible influence on $\mathrm{P}_{\text {Crit }}$, but assessment of $\mathrm{CO}_{2}$ effects have often used ambient $\mathrm{PCO}_{2} \mathrm{~S}$ much above anything that would be expected to normally occur during a few hours in a respirometer.

Adding another voice to the debate, the whole concept of $\mathrm{P}_{\text {Crit }}$ has recently been savaged (Wood, 2018). He also suggests that the method of measurement can influence the value for $\mathrm{P}_{\text {Crit }}$, but goes beyond to suggest "there is no good justification for the concept" and that "it is not a reliable index of hypoxia tolerance". 
Table 1

Examples of routine oxygen consumption measured in air-saturated water of cichlid fishes, including those similarly sized to the Mayan cichlids used in the present study.

\begin{tabular}{|c|c|c|c|c|}
\hline Species & $\begin{array}{l}\text { Body Mass } \\
\text { (g) }\end{array}$ & $\begin{array}{l}\text { Temperature } \\
\left({ }^{\circ} \mathrm{C}\right)\end{array}$ & $\begin{array}{l}\text { Routine } \\
\dot{\boldsymbol{M} O_{2}} \\
(\mu \mathrm{mol} \\
\left.\mathrm{O}_{2} / \mathrm{g} / \mathrm{h}\right)\end{array}$ & Reference \\
\hline Mayan cichlid & 55.4 & $23^{\circ}$ & 2.5 & Present Study \\
\hline (Mayaheros & & $28^{\circ}$ & 4.5 & \\
\hline uropthalmus) & & $33^{\circ}$ & 6.0 & \\
\hline $\begin{array}{l}\text { Convict cichlid } \\
\text { (Cichlosoma } \\
\text { nigrofasciatum) }\end{array}$ & 6.0 & $25^{\circ}$ & 16 & $\begin{array}{l}\text { (Fidhiany and } \\
\text { Winckler, } \\
\text { 1998) }\end{array}$ \\
\hline Tabasco strain of Nile & 8 & $25^{\circ}$ & 5.0 & (Burggren \\
\hline Tilapia & & $30^{\circ}$ & 10.1 & et al., 2019) \\
\hline $\begin{array}{l}\text { (Oreochromis } \\
\text { niloticus) }\end{array}$ & & $35^{\circ}$ & 21.9 & \\
\hline $\begin{array}{l}\text { Nile Tilapia } \\
\begin{array}{l}\text { (Oreochromis } \\
\text { niloticus) }\end{array}\end{array}$ & $220-260$ & $25^{\circ}$ & 2.4 & $\begin{array}{l}\text { (Zeraik et al., } \\
\text { 2013) }\end{array}$ \\
\hline $\begin{array}{l}\text { Lake Magadi tilapia } \\
\qquad(\text { Alcolapia grahami) }\end{array}$ & 3 & $\begin{array}{l}25^{\circ} \\
32^{\circ} \\
39^{\circ}\end{array}$ & $\begin{array}{l}7 \\
13 \\
29\end{array}$ & $\begin{array}{l}\text { (Wood et al., } \\
\text { 2016) }\end{array}$ \\
\hline $\begin{array}{l}\text { Oscar } \\
\qquad \text { (Astronotus ocellatus) }\end{array}$ & 98 & $28^{\circ}$ & 4.1 & $\begin{array}{l}\text { (De Boeck } \\
\text { et al., 2013) }\end{array}$ \\
\hline $\begin{array}{l}\text { Oscar } \\
\quad \text { (Astronotus ocellatus) }\end{array}$ & $156-255$ & $28^{\circ}$ & 4.3 & $\begin{array}{l}\text { (Lewis et al., } \\
\text { 2007) }\end{array}$ \\
\hline $\begin{array}{l}\text { Oscar } \\
\qquad \text { (Astronotus ocellatus) }\end{array}$ & $115-470$ & $28^{\circ}$ & 2.6 & $\begin{array}{l}\text { (Scott et al., } \\
\text { 2008) }\end{array}$ \\
\hline $\begin{array}{l}\text { Mouthbreeding Cichlid } \\
\text { (Pseudocrenilabrus } \\
\text { multicolor) }\end{array}$ & $0.8-4.8$ & $25^{\circ}$ & 7.8 & $\begin{array}{l}\text { (Reardon and } \\
\text { Chapman, } \\
\text { 2010) }\end{array}$ \\
\hline Dwarf Victorian & $4.4-8.7$ & $24^{\circ}$ & 3.4 & (McDonnell \\
\hline Mouthbreeding & & $28^{\circ}$ & 3.1 & and \\
\hline $\begin{array}{l}\text { Cichlid } \\
\text { (Pseudocrenilabrus } \\
\text { multicolor victoriae) }\end{array}$ & & $32^{\circ}$ & 6.9 & $\begin{array}{l}\text { Chapman, } \\
\text { 2016) }\end{array}$ \\
\hline
\end{tabular}

Against this backdrop, the purpose of the current study is not to refute or support the various positions on respirometry and $\mathrm{P}_{\text {Crit }}$ outlined above. Rather, the more focused intent of our study is to correct the record for metabolic physiology of the Mayan cichlid using conventional approaches, as we will now elaborate upon.

\subsection{Routine oxygen consumption of the Mayan cichlid}

The routine $\dot{M O_{2}}$ of the Mayan cichlid measured in the present study is well within the range of those values determined for other warmwater cichlid fishes (Table 1). Presumably mass-specific $\dot{M} \mathrm{O}_{2}$ of the Mayan cichlid will decrease with increasing body mass, as it does in other cichlids and other aquatic and marine fish generally, although this variable was not measured in the present study.

Not surprisingly, routine $\dot{M} \mathrm{O}_{2}$ of the Mayan cichlid increased with acute exposure to increasing temperature at air saturation, from $2.5 \mu \mathrm{mol} \mathrm{O} / 2 / \mathrm{g} / \mathrm{h}$ at $23{ }^{\circ} \mathrm{C}$ to $6.0 \mu \mathrm{mol} \mathrm{O}_{2} / \mathrm{g} / \mathrm{h}$ at $33^{\circ} \mathrm{C}$. $\mathrm{Q}_{10}$ for routine $\dot{\mathrm{MO}} \mathrm{O}_{2}$ calculated over this temperature range was $\sim 2.2$, again well within the range of metabolic temperature sensitivity for tropical freshwater fishes.

\subsection{The Mayan cichlid as oxyregulator}

The higher the rate of tissue oxygen consumption, the more compelling is the need to maintain oxygen consumption despite either internal increase in metabolic demand, or external limitations to oxygen availability. As a consequence, almost every vertebrate that has been examined is a so-called "oxygen regulator" that will evoke physiological adjustments in both perfusion and ventilation of its gas exchange organ (s) (Rogers et al., 2016; Steffensen, 2007). Certainly, the $P_{\text {Crit }}$ varies greatly in fishes, even within a specific grouping such as freshwater fish between $20^{\circ}$ and $36^{\circ} \mathrm{C}$ (Rogers et al., 2016). Nonetheless, $P_{\text {Crits }}$ are typically well below air-saturation water $\mathrm{PO}_{2}$ s. Indeed, only a few fish species have ever been claimed to be oxygen conformers, whereby their rate of oxygen consumption begins to fall when environmental oxygen begins to fall. Examples are the toadfish Opsanus tao (Hall, 1929); the white sturgeon Acipencer transmontanus (Burggren and Randall, 1978), the plaice Pleuronectes platessa (Steffensen et al., 1982) and the swamp eel Synbranchus marmoratus (Graham and Baird, 1984). As a result of these older experiments being repeated with new and or multiple simultaneous oxygen consumption measurement techniques, the number of fish species truly viewed as oxyconformer is rapidly shrinking (Rogers et al., 2016; Steffensen, 2007; Ultsch et al., 1981).

The present study continues the trend of reclassifying oxyconforming fish as oxyregulators by clearly refuting the earlier study by Martínez-Palacios and Ross (1986). We have demonstrated that the Mayan cichlid not only is a true oxyregulator, maintaining $\mathrm{MO}_{2}$ as ambient $\mathrm{PO}_{2}$ falls until quite severe hypoxia is reached, but is a very competent one at that, with $\mathrm{P}_{\text {Crit }} \mathrm{S}$ of $2.60,3.17$ and 4.68 at $23^{\circ}, 28^{\circ}$ and $33^{\circ} \mathrm{C}$, respectively (Fig. 2). In fact, these $\mathrm{P}_{\text {Crit }}$ values for the Mayan cichlid are among the lowest $10-15 \%$ of $\mathrm{P}_{\text {Crit }}$ values for freshwater fishes in the range of $26-33^{\circ} \mathrm{C}$ (Rogers et al., 2016). Low $\mathrm{P}_{\text {Crits }}$ are typically associated with hypoxia tolerance (although the universality of this association has recently been called into question - (Wood, 2018). The observation of very low $\mathrm{P}_{\text {Crit }}$ s fits well with the general observation that the Mayan cichlid can inhabit hypoxic waters and tolerate hypoxic experimental conditions.

Temperature increases the $\mathrm{P}_{\text {Crit }}$ of almost all fishes that have been examined - see (Rogers et al., 2016). Temperature also affected the $P_{\text {Crit }}$ of the Mayan cichlid (Fig. 2), although the differences were not large.

\subsection{Gill ventilatory response to temperature, hypoxia and Hyperoxia}

As anticipated, $\mathrm{f}_{G}$ of Mayan cichlids in air-saturated water increased with acute exposure to increasing temperature (Fig. 4). However, as evident from a $\mathrm{Q}_{10}$ of only $\sim 1.3$ over the range of $23^{\circ}-33^{\circ} \mathrm{C}$, gill ventilation is not particularly temperature sensitive.

Gill ventilation increased markedly with advancing hypoxia at all three measurement temperatures (Fig. 4) reflecting attempts to increase the convective supply of oxygen in the water to the branchial lamellae. However, $\mathrm{f}_{G}$ plateaued or actually decreased at all three temperatures when fish reached severe hypoxia at or below $\mathrm{P}_{\text {Crit }}$ levels. Interestingly, it appeared that even high temperatures and severe advancing hypoxia could not drive gill ventilation rates above $80-90$ breaths/min at either $28^{\circ}$ or $33^{\circ} \mathrm{C}$, suggesting a possible upper limit to gill ventilation rates under these conditions.

Many vertebrates have a so-called 'hypoxic drive' for ventilation demonstrated by the depression of ventilation when ambient $\mathrm{PO}_{2} \mathrm{~S}$ are experimentally elevated well above normoxic levels (Florindo et al., 2018; Haouzi et al., 2014; Porteus et al., 2015; West et al., 1989). Gill ventilation in the Mayan cichlid appears to also have a strong hypoxic drive, with significant, considerable depression of $\mathrm{f}_{G}$ occurring when ambient $\mathrm{PO}_{2} \mathrm{~S}$ are increased well above air-saturation levels (Fig. 4B). The hypoxic drive is generally thought to result from chemoreceptor influences on central pattern generators stimulating lung or gill ventilation (Florindo et al., 2018; Haouzi et al., 2014). Certainly the existence of both of peripheral and central chemoreceptors has been well established in both aquatic and airbreathing fishes (Florindo et al., 2018; Jonz, 2018; Jonz et al., 2015; Perry et al., 2009; Zaccone et al., 2018). While the metabolic physiology of the cichlids has been well studied, far less is known about chemoreceptor function and influences in cichlids.

\subsection{Conclusions}

The Mayan cichlid has been shown in this study to be a highly competent oxyregulator, maintaining routine $\mathrm{MO}_{2}$ at control rates until 
$\mathrm{PO}_{2}$ has decreased to $<2-3 \mathrm{kPa}$. This maintenance of $\dot{M} \mathrm{O}_{2}$ is aided in part by a considerable branchial hyperventilation. These data refute an earlier observation that the Mayan cichlid is an oxyconformer, and support the ecological data that indicates that this species can inhabit very warm, hypoxic aquatic habitats.

\section{Funding}

This work was support by US National Science Foundation Operating Grant 1025823. The UAEM grants "Collaboration Network in Comparative Ecophysiology of Vertebrates" PRODEP 11067 and "Scientific Research, Innovation, and Development" 4503/2018/CI also provided support.

\section{Declaration of interest}

None.

\section{References}

Almeida-Val, V., Farias, I.P., Silva, M.N., Duncan, W.P., Val, A.L., 1995. Biochemical adjustments to hypoxia by Amazon cichlids. Brazilian J. Med. and Biol. Res. Nov-Dec $28,1257-1263$.

Baptista, R.B., Souza-Castro, N., Almeida-Val, V.M., 2016. Acute hypoxia up-regulates HIF-1 $\alpha$ and VEGF mRNA levels in Amazon hypoxia-tolerant Oscar (Astronotus ocellatus). Fish Physiol. Biochem. 42, 1307-1318.

Burggren, W.W., Randall, D.J., 1978. Oxygen uptake and transport during hypoxic exposure in the sturgeon Acipenser transmontanus. Respir. Physiol. 34, 171-183.

Burggren, W.W., Mendez-Sanchez, J.F., Bautista Martinez, G., Peña, E., Martínez García, R., Alvarez González, C.A., 2019. Developmental changes in oxygen consumption and hypoxia tolerance in the heat- and hypoxia-adapted Tabasco line of the nile tilapia (Oreochromis niloticus), with a survey of the metabolic literature for the genus Oreochromis. J. Fish Biol. 94, 732-744.

Chavez-Lopez, R., Peterson, M.S., Brown-Peterson, N.J., Morales-Ǵomez, A.A., FrancoĹopez, J., 2005. Ecology of the Mayan cichlid, Cichlasoma urophthalmus Gunther, in the Alvarado lagoonal system. Veracruz. Gulf Caribb. Res. 17, 121-131.

De Boeck, G., Wood, C.M., Iftikar, F.I., Matey, V., Scott, G.R., Sloman, K.A., de Nazare Paula da Silva, M., Almeida-Val, V.M., Val, A.L., 2013. Interactions between hypoxia tolerance and food deprivation in Amazonian oscars, Astronotus ocellatus. J. Exp. Biol. 216, 4590-4600.

Faunce, C.H., Lorenz, J.J., 2000. Reproductive biology of the introduced Mayan cichlid, Cichlasoma urophthalmus, within an estuarine mangrove habitat of Southern Florida. Environ. Biol. Fish 58, 215-225.

Fidhiany, L., Winckler, K., 1998. Influence of body mass, age, and maturation on specific oxygen consumption in a freshwater cichlid fish, Cichlasoma nigrofasciatum (Gunther, 1869). Comp. Biochem. and Physiol. A Mol. and Integr. Physiol. 119, 613-619.

Florindo, L.H., Armelin, V.A., McKenzie, D.J., Rantin, F.T., 2018. Control of air-breathing in fishes: central and peripheral receptors. Acta Histochem. 120, 642-653.

Graham, J.B., Baird, T.A., 1984. The transition to air brething in fishes: III. Effects of body size and aquatic hypoxia on the aerial gas exchange of the swamp eel Synbranchbus marmoratus. J. Exp. Biol. 108, 357-375.

Hall, F.F.G., 1929. The influence of varying oxygen tension upon the rate of oxygen consumption in marine fishes. Am. J. Phys. 88, 212-218.

Haouzi, P., Sonobe, T., Chenuel, B., 2014. Oxygen-related chemoreceptor drive to breathe during $\mathrm{H}_{2} \mathrm{~S}$ infusion. Respir. Physiol. Neurobiol. 201, 24-30.

Jonz, M.G., 2018. Insights into the evolution of polymodal chemoreceptors. Acta Histochem. 120, 623-629.

Jonz, Michael G., Zachar, Peter C., Da Fonte, Dillon F., Mierzwa, Anna S., 2015. Peripheral chemoreceptors in fish: a brief history and a look ahead. Comp. Biochem. and Physiol. A Mol. and Integr. Physiol. 186, 27-38.

Lewis, J.M., Costa, I., Val, A.L., Almeida-Val, V.M., Gamperl, A.K., Driedzic, W.R., 2007. Responses to hypoxia and recovery: repayment of oxygen debt is not associated with compensatory protein synthesis in the Amazonian cichlid, Astronotus ocellatus. J. Exp. Biol. 210, 1935-1943.

Loftus, W.F., 1987. Possible establishment of the mayan cichlid, Cichlasoma urophthalmus (Günther) (Pisces:Cichlidae), in Everglades National Park. Florida. Fla. Sci. 50, 1-6.

Mandic, M., Todgham, A.E., Richards, J.G., 2009. Mechanisms and evolution of hypoxia tolerance in fish. Proceedings. Biol. Sci. Royal Soc. 276, 735-744.

Martínez-Palacios, C.A., Ross, L.G., 1986. The effects of temperature, body weight and hypoxia on the oxygen consumption of the Mexican mojarra, Cichlasoma urophthalmus (Günther). Aquac. Fish. Manag. 17, 243-248.

Martínez-Palacios, C.A., Ross, L.G., 2004. Post-hatching geotactic behaviour and substrate attachment in Cichlasoma urophthalmus (Günther). J. Appl. Ichthyol. 20, 545-547.
Martínez-Palacios, C.A., Chávez-Sánchez, C., Olvera Novoa, M.A., 1993. The potential for culture of the American Cichlidae with emphasis on Cichlasoma urophthalmus. In: Muir, Roberts (Ed.), Recent advances in aquaculture. Blackwell, Oxford.

McDonnell, L.H., Chapman, L.J., 2016. Effects of thermal increase on aerobic capacity and swim performance in a tropical inland fish. Comp. Biochem. and Physiol. A Mol. and Integr. Physiol. 199, 62-70.

Miller, R.R., Minckley, W.L., Norris, S.M., 2005. Freshwater Fishes of Mexico. University of Chicago Press, Chicago, Illinois.

Nico, L.G., Beamish, W.H., Musikasinthorn, P., 2007. Discovery of the invasive Mayan Cichlid fish "Cichlasoma" urophthalmus (Günther 1862) in Thailand, with comments on other introductions and potential impacts. Aquat. Invasions (3), 197-214.

Paperno, R., Ruiz-Carus, R., Krebs, J.M., McIvor, C.C., 2008. Range expansion of the Mayan cichlid, Cichlasoma urophthalmus (Pisces, Cichlidae), above $28^{\circ} \mathrm{n}$ latitude in Florida. Fla. Sci. 71, 293-304.

Perry, S.F., Jonz, M.G., Gilmour, K.M., 2009. Oxygen sensing and the hypoxic ventilatory response. In: Brauner, Richards Farrell (Ed.), Fish Physiology: Hypoxia. Academic Press, pp. 193-253 (New York).

Porteus, C.S., Pollack, J., Tzaneva, V., Kwong, R.W., Kumai, Y., Abdallah, S.J., Zaccone, G., Lauriano, E.R., Milsom, W.K., Perry, S.F., 2015. A role for nitric oxide in the control of breathing in zebrafish (Danio rerio). J. Exp. Biol. 218, 3746-3753.

Reardon, E.E., Chapman, L.J., 2010. Energetics of hypoxia in a mouth-brooding cichlid: evidence for interdemic and developmental effects. Physiol. Biochem. Zool. 83, 414-423.

Regan, M.D., Richards, J.G., 2017. Rates of hypoxia induction alter mechanisms of O2 uptake and the critical O2 tension of goldfish. J. Exp. Biol. 220, 2536-2544.

Regan, M.D., Gill, I.S., Richards, J.G., 2017. Calorespirometry reveals that goldfish prioritize aerobic metabolism over metabolic rate depression in all but near-anoxic environments. J. Exp. Biol. 220, 564-572.

Rodgers, G.G., Tenzing, P., Clark, T.D., 2016. Experimental methods in aquatic respirometry: the importance of mixing devices and accounting for background respiration. J. Fish Biol. 88, 65-80.

Rogers, N.R., Urbina, M.A., Reardon, E.E., McKenzie, D.J., Wilson, R.W., 2016. A new analysis of hypoxia tolerance in fishes using a database of critical oxygen level (Pcrit). Conserv. Physiol. 4, 1-19.

Schofield, P.J., Loftus, W.F., Fontaine, J.A., 2009. Salinity effects on behavioural response to hypoxia in the non-native Mayan cichlid Cichlasoma urophthalmus from Florida Everglades wetlands. J. Fish Biol. 74, 1245-1258.

Schofield, P.J., Loftus, W.F., Kobza, R.M., Cook, M.I., Slone, D.H., 2010. Tolerance of nonindigenous cichlid fishes (Cichlasoma urophthalmus, Hemichromis letourneuxi) to low temperature: laboratory and field experiments in South Florida. Biol. Invasions $12,2441-2457$.

Scott, G.R., Wood, C.M., Sloman, K.A., Iftikar, F.I., De Boeck, G., Almeida-Val, V.M., Val, A.L., 2008. Respiratory responses to progressive hypoxia in the Amazonian oscar, Astronotus ocellatus. Respir. Physiol. Neurobiol. 162, 109-116.

Snyder, S., Nadler, L.E., Bayley, J.S., Svendsen, M.B., Johansen, J.L., Domenici, P., Steffensen, J.F., 2016. Effect of closed v. intermittent-flow respirometry on hypoxia tolerance in the shiner perch Cymatogaster aggregata. J. Fish Biol. 88, 252-264.

Stauffer, J.R., Boltz, S.E., 1994. Effect of salinity on the temperature preference and tolerance of age-0 Mayan cichlids. Trans. Am. Fish. Soc. 123, 101-107.

Steffensen, J.F., 2007. Oxygen consumption of fish exposed to hypoxia: Are they all oxyregulators or are any oxyconformers? In: Brauner, Suvajdzic, Nilsson, Randall (Eds.), Proceedings of the Ninth International Symposium, Capri, Italy, April 24-28. Ecosystems Research Division, U.S. Environmental Protection Agency, Office of Research and Development, Washington, D.C, pp. 2006.

Steffensen, J.F., Lomholt, J.P., Johansen, K., 1982. Gill ventilation and $\mathrm{O}_{2}$ extraction during graded hypoxia in two ecologically distinct species of flatfish, the flounder (Platichthys flesus) and the plaice (Pleuronectes platessa). Environ. Biol. Fish 7, 157-163.

Tian, R., Losilla, M., Lu, Y., Yang, G., Zakon, H., 2017. Molecular evolution of globin genes in Gymnotiform electric fishes: relation to hypoxia tolerance. BMC Evol. Biol. $17,51$.

Ultsch, G.R., Jackson, D.C., Moalli, R., 1981. Metabolic oxygen conformity among lower vertebrates: the toadfish revisited. J. Comp. Physiol. 142, 439-443.

West, N.H., Smits, A.W., Burggren, W.W., 1989. Factors terminating nonventilatory periods in the turtle, Chelydra serpentina. Respir. Physiol. Neurobiol. 77, 337-349.

Wood, C.M., 2018. The fallacy of the $P_{\text {Crit }}$ - are there more useful alternatives? J. Exp. Biol. 221, jeb163717.

Wood, C.M., Brix, K.V., De Boeck, G., Bergman, H.L., Bianchini, A., Bianchini, L.F., Maina, J.N., Johannsson, O.E., Kavembe, G.D., Papah, M.B., Letura, K.M., Ojoo, R.O., 2016. Mammalian metabolic rates in the hottest fish on earth. Sci. Rep. 6, 26990.

Yeager, D.P., Ulstch, G.R., 1989. Physiological regulation and conformation: a BASIC program for the determination of critical points. Physiol. Zool. 62, 888-907.

Zaccone, G., Lauriano, E.R., Capillo, G., Kuciel, M., 2018. Air- breathing in fish: airbreathing organs and control of respiration: Nerves and neurotransmitters in the airbreathing organs and the skin. Acta Histochem. 120, 630-641.

Zeraik, V.M., Belao, T.C., Florindo, L.H., Kalinin, A.L., Rantin, F.T., 2013. Branchial $\mathrm{O}_{2}$ chemoreceptors in Nile tilapia Oreochromis niloticus: control of cardiorespiratory function in response to hypoxia. Comp. Biochem. and Physiol. A Mol. and Integr. Physiol. 166, 17-25. 